\title{
The Role Of Police Investigators In Overcoming Motor Vehicle Theft (Curanmor) In Police Area Pakpak Bharat Resort
}

\section{Widodo Kaban}

Sumatera University Faculty Of Law. E-mail: widodokaban@gmail.com

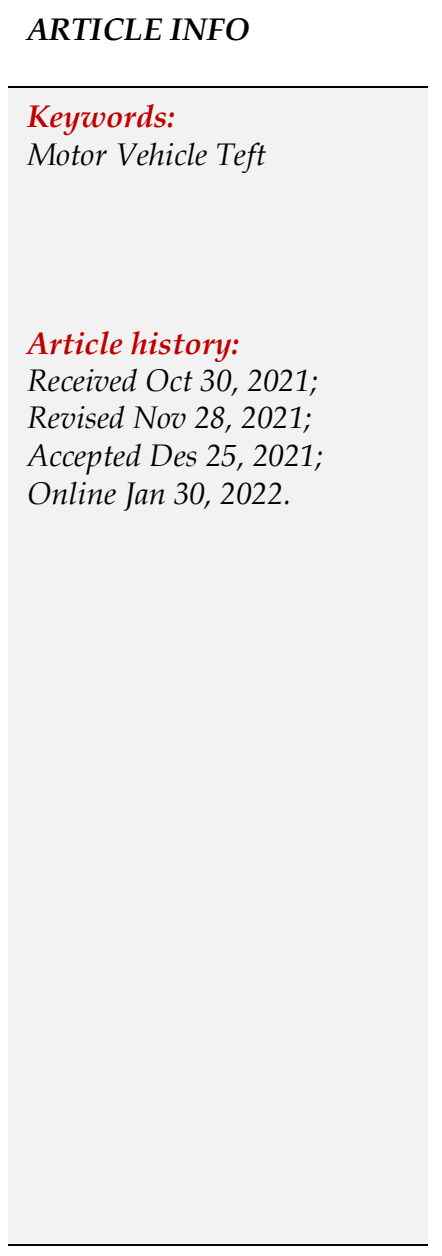
\begin{abstract}
The increase in cases of motor vehicle theft cannot be avoided due to the increasing growth rate of motorized vehicles which is quite high in the Pakpak Bharat Resort Police (Polres). The Ministry of Transportation said that the growth rate of motorized vehicles was very disproportionate to the length of the existing road, that the length of the road was no longer able to accommodate the volume of motorized vehicles. The problems posed are: what is the form of the act of motor vehicle theft in Pakpak Bharat, what is the role of the police in motor vehicle theft in Pakpak Bharat and what are the obstacles and efforts faced by the police in overcoming motor vehicle theft. The results of the research and discussion explain that the forms of theft of motorized vehicles in Pakpak Bharat are carried out in various ways, namely: using fake keys, damaging motorized ignition keys, damaging four-wheeled motorized vehicle doors, pointing with firearms and pointing with sharp weapons as well as depriving and take by force by injuring the victim. The role of the National Police in motor vehicle theft in Pakpak Bharat is to conduct investigations and take action on public reports of motor vehicle theft, with details of the main tasks as follows: as law enforcers, as protectors and as community guides. Efforts that can be made by the police in overcoming motor vehicle theft are by conducting raids and patrols in places that are suspected of being prone to motor vehicle theft and socialization about the use of additional keys. The obstacle faced by the police in overcoming the theft of motor vehicles is the difficulty in identifying the perpetrators of the theft. Motor vehicle theft is currently experiencing growth and development with neat characteristics, has a kind of bureaucracy of its own, is resistant to social reactions and is able to spread a network of activities in such a way that it has a wide scope coupled with a high quality to avoid law enforcement efforts through various means.
\end{abstract}

This is an open access article under the CC BY-NC license.

\section{Introduction}

Crime cases that occur in society today are very diverse. Conventional crime cases that disrupt security and order in society include murder, violent theft, weight theft, motor vehicle theft, fire, rape, extortion, narcotics abuse, juvenile delinquency and gambling. These crimes usually occur in urban areas. This situation is very worrying for the community it self.

The problem of increasingly complicated crime occurs in all levels of society without exception. The diverse community environment greatly influences a person in committing crimes. The big city environment that is dense and busy with various activities facilitates the occurrence of a 
crime. The individualistic attitude of the community results in weak supervision from the community towards disturbances in security and order that occur. Soerjono Soekanto said that society has undergone a change in culture and values towards a pre-modern society with the most prominent individualistic characteristics resulting in less intimate relationships between humans and then gave rise to the lu-lu and me-gue culture.Lately, there is a tendency to increase crime cases against motor vehicle theft. Apart from injuring the victims of their crimes, the perpetrators also have the heart to take the lives of others. The crime of theft of motorized vehicles with violence usually afflicts motorcycle taxi drivers as is often the case lately.

Considerable attention is given by the media, both print media and national electronic media. Reports on cases of theft crimes almost every day adorn the front pages of national print media or are broadcast in special criminal programs that appear on every national television station. The increase in cases of motor vehicle theft cannot be avoided due to the increasing growth rate of motorized vehicles which is quite high in the Pakpak Bharat Resort Police (Polres). The Department of Culture, Tourism, Transportation, Parks and Hygiene of Pakpak Bharat Regency said that the growth rate of motorized vehicles was very disproportionate to the length of the existing road, that the length of the road was no longer able to accommodate the volume of motorized vehicles.

Negligence in paying attention to safety factors will facilitate the occurrence of motor vehicle theft crimes. Roadside parking lots, offices, schools, campuses and shopping centers are the most vulnerable places in the occurrence of motor vehicle theft crimes. Indications of the increase in motor vehicle theft crimes are not only caused by the growth rate of motorized vehicles, but are also shown by the number of reports of motor vehicle losses received by the authorities, in this case the police. Reports received by the Pakpak Bharat Police during 2011 stated that the crime rate for motor vehicle theft was quite high. The crime rate of motor vehicle theft in the jurisdiction of the Pakpak Bharat Police is quite significant.

\section{Method}

This type of research is juridical normative, namely research that aims to describe systematically, factually and accurately on a situation that is the object of research by basing research on normative legal provisions. In this normative juridical research, a situation or phenomenon will be described related to the study of the role of Polri investigators in overcoming motor vehicle theft (Curanmor) in the Pakpak Bharat Resort Police area.

The data collection method used to collect data in this study was through document studies in the form of data collection from literature or scientific writings in accordance with the object under study and field research at the Pakpak Bharat Resort Police conducted by interview. The type of analysis used in this study is a qualitative analysis that describes the phenomena regarding the results of the study with sentences so that it can solve the problem formulation.

\section{Analysis And Results}

\subsection{The Role Of The Police In The Theft Of Motor Vehicles In Pakpak Bharat}

\section{a. The Role and Duties of the Police as Law Enforcers}

Law enforcement that is generally expected by the community as a police function is enforcing the criminal law. As an instrument of the state, the police are responsible for carrying out some of the day-to-day tasks of the government, which are to give rise to part of the daily tasks of the government, which are to create a sense of security for the citizens. This government task is carried out by the police through the enforcement of criminal law, particularly through crime 
prevention and solving crimes that occur. But in an effort to create this sense of security, the police are also tasked with maintaining order and order.

In carrying out their work the police are not easy to separate the two functions, namely between enforcing criminal law and maintaining order. However, for the purposes of analysis, the two functions must be distinguished because they involve different professional abilities The Police Act (Law No. 2 of 2002) provides for the and very broad powers to the police. This mandate can essentially be divided into two broad categories. The first is to prevent and investigate crimes in which the police will appear as an instrument of the state (law enforcement). The second mandate is a bit more difficult to describe, the police here are tasked with maintaining order and order in society. The desired face of the police here is as a protector, who provides protection and services to the community.

These two faces of the police, as law enforcers and as protectors, characterize the duties and authorities of the Indonesian police and also create a police culture that will determine its credibility in society. As mentioned above, the community wants the police to enforce the criminal law by preventing citizens from becoming victims of crime and even if there are citizens who become victims, the police must disclose the crime and arrest the perpetrators. Especially with regard to violent crimes and serious crimes there is strong public pressure for the police to do their job quickly.

However, in this law enforcement effort, the task of the police is not only about serious crimes with violence. The police are also required to enforce the law in minor crimes. More broadly, the police are also required to enforce administrative regulations (which often have criminal sanctions). The police described above are "law enforcers" and as "crime fighters". Especially as a crime fighter against violent and serious fighters. In this role, the police must take proactive crime fighter initiatives. In this role the police must take the initiative to prevent criminals and not only act when the victim asks for help. Police work in incidents like this can be likened to "using fire to put out fires", because police are often expected to use "violence". The credibility of the police here is often haunted (scared by bad people, who are also citizens of the community). The pure image of the community that the police should be feared is also seen in the case of a mother threatening her naughty child to be summoned by the police.

The image of the police as law enforcers is also complicated by the ambivalent attitude of the community. On the one hand, the community members expect protection from the police against bad people, who are in the community, but on the other hand they do not like it when the police use coercive measures (searching, arresting, and detaining) themselves. This ambivalent attitude (dual: sympathy but also dislike) makes it difficult for the police. This can cause conflict in a policeman in finding his identity.

\section{1) Police as Investigators}

The police are known as investigators, as well as from the tasks assigned by Law no. 2 of 2002, the police in carrying out their duties and authorities act as police. The police also play a role as a supervisor on the activities of civil servants in conducting investigations. Civil servants in a government agency who have been appointed by the Minister of Justice as civil servant investigators, in carrying out their duties and authorities must be under the coordination of the Police, as has been confirmed in Law no. 8 of 1981 (KUHAP) in Article 7 paragraph (2) which reads: Investigators as referred to in Article 6 paragraph (1) letter b, have the authority in accordance with the law which is the legal basis for each and in carrying out their duties are under the coordination and supervision of investigators as referred to in Article 6 paragraph (1) letter a. From the provisions of this article, it means that civil servant officials must have a working relationship with Polri investigators. Now the problem arises, namely, what kind of working relationship is meant here. Whereas in the working relationship between Polri investigators and civil servant officials as regulated in Law no. 8 of 1981 covers the 
implementation of coordination, supervision, giving instructions and providing investigative assistance from investigators to civil servant investigators based on the joints of functional relationships. That what is meant by a working relationship between investigator Polri and civil servant investigators is a functional working relationship to realize coordination, integration and synchronization in carrying out the duties, functions and roles of Polri with other government agencies in the context of carrying out investigations of certain criminal acts. That in order to guarantee legal certainty and for the smooth implementation of the above relations, the Department of Defense and Security at the Indonesian National Police Headquarters has issued technical instructions no. Pol : Juknis/05/XI/1983 concerning the working relationship between Polri investigators and civil servant officials, followed by the Decree of the Chief of Police of the Republic of Indonesia No. Pol : SKEP/369/X/1985 concerning the mechanism for coordination and supervision of civil servant officials. Well, from the two regulations, the implementation of the working relationship between the police investigators and civil servants will be discussed, which, among other things, the working relationship includes:

\section{a) Coordination}

Coordination is a working relationship between Polri investigators and civil servant officials, in the context of carrying out investigations of criminal acts committed Concerning field certain, on base connection functional with respect their respective hierarchies.

\section{b) Supervision}

Supervision is the process of observing rather than carrying out all investigation activities of civil servant officials in the context of carrying out investigations to ensure that all investigative activities that are being carried out can be justified materially and formally and run in accordance with applicable legal provisions. In connection with this, namely regarding how the form/pattern of supervision is carried out by Polri investigators, then let's look at Law no. 8 of 1981 in conjunction with technical instructions Pol Number : Juknis/05/XI/1983.

\section{c) Giving instructions}

Instructions are demands or technical investigation guidance given by Polri investigators to civil servant investigators in the context of carrying out investigations, the guidance is both technical and tactical. Whereas in order to ensure the implementation of coordination and supervision as well as possible, the Indonesian National Police investigators provide instructions and are asked or not requested based on their responsibilities to provide the necessary investigative assistance. As for the basis of the provision of these instructions, we can see from the provisions of Law no. 8 of 1981.

d) Investigation assistance

Whereas sometimes the facilities and infrastructure owned by civil servant investigators in an effort to carry out investigations are not as complete and as good as those owned by Polri investigators, so that in carrying out their duties carrying out investigations, they are most likely to have to ask for investigative assistance from Polri investigators, both technical assistance and tactical assistance.

e) Tactical Assistance.

What is meant by technical assistance is in the form of personnel and equipment in the context of investigations by police investigators in order to assist civil servant investigators in the field of certain criminal acts as long as it complies with the provisions of the law. That the assistance of personnel and equipment provided by Polri investigators to civil servant investigators can in essence be in the form of personal personnel, especially in the context of carrying out efforts and confiscation. Likewise, assistance in the form of equipment in order to support the success 
of the investigation, such as weapons, means of transportation and so on. So these are some forms of implementation patterns rather than working relationships between Polri investigators and civil servant investigators in the context of realizing coordination and supervision in the process of investigating certain crimes, which in this case are criminal acts in the immigration sector.

\section{b. The Role of the Police in the Theft of Motor Vehicles in Pakpak Bharat}

In the era of the monetary crisis as it is currently happening, it has resulted in the difficulty of the economy and also has resulted in an increase in the number of crimes, especially the crime of motor vehicle theft, which in this case the role of the police needs to be further enhanced so that every case of motor vehicle theft can be disclosed so as to provide feedback. for reducing the value of the quantity of motor vehicle theft. Tackling the problem of motor vehicle theft can not only be left to the police but carried out together with the community. Basically the police can only give warnings to the public about being careful in terms of providing security to motorized vehicles. Basically the role of the police in dealing with motor vehicle theft is based on the following methods:

\section{1) Prevention method}

The purpose of the prevention method is to provide motivation, guidance and direction to the community, especially regarding the procedures for securing vehicles owned by the community so that people understand and realize it.

In this method what is meant is how to prevent the emergence of opportunities for certain parties to commit crimes of motor vehicle theft. Supervision in this case is intended to be a control to suppress the incidence of the crime of motor vehicle theft in a society. In terms of police action, basically in the form of patrolling and placing personnel in areas prone to motor vehicle theft, such as parking areas and other places.

\section{2) Reform Method}

What is meant by this method is how and what efforts must be made so that a crime of motor vehicle theft that has occurred can be caught. In this capacity, the implementation of this reform method is basically as described earlier by coordinating between the police, both between sectors and between regions. This exchange of information becomes important, especially in terms of uncovering a crime of motor vehicle theft. The police also conduct searches by looking for information on certain parties, for example, perpetrators caught redhanded in theft of motorized vehicles and looking for collectors from the stolen vehicle.

\subsection{Obstacles And Efforts Faced By Police In Overcoming Motor Vehicle Theft}

\section{a. Motor Vehicle Theft Investigation Process}

In general, the investigation of motor vehicle theft in a criminal procedure can be carried out against a suspect if that person has committed a crime or a criminal event of motor vehicle theft. Criminal events can be identified through:

1) Reports or complaints,

2) Press releases.

3) Found caught red-handed.

An incident includes the question of whether it is true that there has been a criminal incident of motor vehicle theft and who is the culprit (deder). The purpose of the examination is, first of all, so that investigators can consider whether or not the crime of motor vehicle theft has occurred. In this case in the world of legal science there are 2 (two) examination systems that can be adopted, namely:

1) inquisitoir inspection system, 
This system considers the defendant as an object, an item that must be examined for its substance in connection with an indictment. This physical examination is in the form of hearing the suspect about himself personally. Since there has been an accusation which has more or less been confirmed by the accuser through sources of knowledge outside the suspect, the suspect's hearing should be an incentive for the suspect to admit his guilt. This prompting interest in a false confession is usually related to the nature of the accuser as a mere human being, is so great that in practice this encouragement takes the form of persecution. This system is used at the preliminary examination level and this inspection system occurs during HIR in Indonesia.

\section{2) Accusator check system.}

This system considers the defendant as an object, an item that must be examined for its substance in connection with an indictment. This physical examination is in the form of hearing the suspect about himself personally. Since there has been an accusation which has more or less been confirmed by the accuser through sources of knowledge outside the suspect, the suspect's hearing should be an incentive for the suspect to admit his guilt. This prompting interest in a false confession is usually related to the nature of the accuser as a mere human being, is so great that in practice this encouragement takes the form of persecution. This system is used at the preliminary examination level and this inspection system occurs during HIR in Indonesia.

\section{3) Accusatoir examination system (meaning: accuse).}

This system considers a suspect/defendant as a subject dealing with another party who accuses, namely the police or the prosecutor's office, in such a way that both parties each have rights of equal value, and the judge is above both parties. This is to settle the matter of criminal cases between them according to the applicable criminal law regulations.

\section{b. Efforts Made by the Police to Overcome the Theft of Motor Vehicles}

Efforts to overcome the Pakpak Bharat Police are considered not optimal, because in the results of the last operation, the Pakpak Bharat Police Ranmor during 2011 only succeeded in revealing a few cases of operational targets or TO ranmor. These cases are the main targets because the perpetrators are professional recidivists and are difficult to catch. The perpetrators are also people who have been targeted by the Pakpak Bharat Police for operations or TO. In delegating the case to the prosecutor's office, the Pakpak Bharat Police only delegated a few complete motor vehicle theft case files, because in other cases it was stated that there was not enough evidence of a crime in the form of a motor vehicle because the evidence of the crime of theft had not been found.

In carrying out the main tasks of the police to always maintain security and public order, and enforce the law and provide protection, protection, and service to the community, it is appropriate for the police in this case the Pakpak Bharat Police to carry out their duties by prioritizing preventive efforts or preventive measures and repressive efforts or taking action. by reviewing an event that occurred in accordance with the provisions stipulated in Law Number 2 of 2002 concerning the Indonesian National Police.

The Pakpak Bharat Police said that in addition to carrying out prevention efforts in the form of initial security to anticipate the occurrence of theft crime cases, the Pakpak Bharat Resort Police carried out efforts to overcome theft crimes.

The first effort is to carry out routine patrols or routine operations in areas prone to theft. If the operation or patrol is not optimal, the Pakpak Bharat Police will hold a special operation for theft. The policy for conducting patrols is in accordance with the Indonesian National Police, where the police must always maintain order and ensure public security. The next effort made by the Pakpak Bharat Police is to carry out special operations by conducting raids on motorized 
vehicles, both raids for motorized vehicle completeness and raids for completeness of motorized vehicle documents. In carrying out this special operation, the Criminal Investigation Unit cooperates with the Traffic Unit. The motor vehicle operation is carried out by patrolling areas that are considered prone to theft crimes.

\section{c. Obstacles Faced by the Police in Combating Motor Vehicle Theft}

In all fields that can be thought of, there are always problems, and it is not uncommon in doing a job to be faced with various problems that were previously unimaginable.

The development of human civilization as well as the growth of science which is closely related to various aspects of human life, is now facing a vast ocean full of problems, especially the dangers of overcoming theft which from year to year continues to increase, especially in big cities and villages. village.

The main obstacle for the police in revealing cases of motor vehicle theft is the lack of police officers compared to the high rate of motor vehicle theft, so that this results in a split in concentration from one case to another. In fact, although many perpetrators of motor vehicle theft are caught red-handed, there are still other perpetrators. In fact, the police also warn the public to install security locks on their vehicles. The warning was carried out by the police in the form of banners, but in this case cooperation was also not given by the community. So that people can easily park their motorized vehicles in any place without a safety lock so that it provides an opportunity for perpetrators of motor vehicle theft to continue their intentions.

\section{Conclusion}

The development of motor vehicle theft in Pakpak Bharat is carried out in various ways, namely: using fake keys, damaging motor vehicle ignition keys, damaging four-wheeled motorized vehicle doors, pointing with firearms and pointing with sharp weapons as well as looting and taking force by injuring the victim.

The role of the National Police in motor vehicle theft in Pakpak Bharat is to conduct investigations and take action on public reports of motor vehicle theft, with details of the main tasks as follows: as law enforcers, as protectors and as community guides.

Efforts that can be made by the police in overcoming motor vehicle theft are by conducting raids and patrols in places that are suspected of being prone to motor vehicle theft and socialization about the use of additional keys. The obstacle faced by the police in overcoming the theft of motor vehicles is the difficulty in identifying the perpetrators of the theft.

\section{References}

Adami Chazawi, Crimes Against Property, Bayu Media, Malang, 2003.

Ministry of National Education, Big Indonesian Dictionary, PN. Balai Pustaka, Jakarta, 2003.

Kelik Pramudya and Ananto Widiatmoko, Guidelines for Professional Ethics of Law Apparatus, Yustisia Library, Yogyakarta, 2010.

Mardjono Reksodiputro, Police and Society in the Reformation Era, Police as Law Enforcers, Indonesian Police Journal, Year I, September 1999-April 2000.

Mardjono Reksodiputro, Criminology and Criminal Justice System, Center for Justice Services and Legal Services, University of Indonesia, Jakarta, 1994. 
Martiman Prodjohamidjojo, Position of Suspect and Defendant in Examination, Justice Equity Series, 1991.

M. Yahya Harahap, Discussion of Problems and Application of the Criminal Procedure Code, Investigation and Prosecution, Second Edition, Sinar Graphic, Jakarta, 2002.

Riduan Syahrani, Some Things about Criminal Procedure Law, Alumni, Bandung, 1983.

R. Soesilo, The Criminal Code and its Explanation, Politeia, Bogor, 1984.

Sadjijono, Police Law and Good Governance, Laksbang Mediatama, Jakarta, 2008.

Soedjono CH, Criminology Doctrine, Pradnya Paramita, Jakarta, 1974.

Soedjono, Preliminary Examination According to the Criminal Procedure Code, Alumni, Bandung, 1983.

Soerjono Soekanto, Sociology of a Conveyor, University of Indonesia Publishing Foundation, Jakarta, 1993.

Soerjono Soekanto, Several Sociological Theories About the Structure of Society, UI Press, Jakarta, 1983.

Wirjono Prodjodikoro, Certain Crimes in Indonesia, Eresco, Bandung, 1986.

Zamnari Abidin, Criminal Law in Scheme, Ghalia Indonesia, Jakarta, 1984.

Law No. 2 of 2002 concerning the National Police of the Republic of Indonesia KUHAP. 